\title{
Autonomy by Law: The Only Direction of Institutional Development of Villagers' Autonomy in China
}

\section{Based on Investigations to the Experience of Some Rural Areas}

\author{
Mao Mingchen ${ }^{1}$, Mao Rui ${ }^{2, a}$ \\ ${ }^{1}$ Law School, Zhejiang University of Finance and Economics, 310018 Hangzhou Zhejiang, China. \\ ${ }^{2}$ School of Management, Zhejiang University, 310058 Hangzhou Zhejiang, China.
}

\begin{abstract}
The villagers' autonomy in China, which started from the 1980s, has been limited by the social, especially the political and legal, conditions. Only a partial realization was eventually realized amid the inevitable influence from the central power. As the experience of some rural Chinese areas demonstrates, autonomy by law is the only direction of institutional development of villagers' autonomy. However, in the current environment of historical habits, legal practice, mental thoughts, economic and social mortality, and politics, the villagers' autonomy is more easily prone to the power rather than laws. To facilitate autonomy by law, the following strategies thus bear particular importance: (1) improve the legislation system to pave the way for the rule of law; (2) change rural governments' attitude towards villagers' autonomy and replace the intrusion by the macro direction; (3) abandon redundant government regulations to guarantee autonomy; (4) establish the system of legal remedy as a legal protection.
\end{abstract}

Keywords. villagers' autonomy; legalization; grassroots democracy

\section{Introduction}

Villagers' autonomy emerged in the 1980s in China. Due to the restrictions of the historical social, political, and legal conditions, the practice, however, was substantially suffered from the influence of the central government. Its role to spark a nationwide democracy was also impaired.

\section{The conundrum of autonomy by law}

\subsection{Interventions made the government unable to change its role}

According to the Program for Comprehensively Promote Administration by Law issued by the State Council, the traditional role of governments at all levels must change by 2014 and the rule of law will be realized. The practice of grassroots democracy and villagers' autonomy shall serve this objective in theory. But in reality, the practice hindered the change of the government's role instead, as the

\footnotetext{
${ }^{a}$ Corresponding author: rmao@zju.edu.cn
}

This is an Open Access article distributed under the terms of the Creative Commons Attribution License 2.0, which permits unrestricted use, distribution, and reproduction in any medium, provided the original work is properly cited. 
overdue government intrusions into the autonomy led the expected restrictions on government management to "guidance, assistance and help", specified in the Organic Law of Villagers Committees of the People's Republic of China (hereafter referred as the Organic Law of Villagers Committees), impossible.

\subsection{The coherent legal system was damaged by the implementation through policies}

Although China's villagers' autonomy is regulated by the Organic Law of Villagers Committees, with respect to its implementation however, it is more proper to say it was driven by policies rather than the law, because provincial governments and even township authorities all specified policy files as to how the autonomy shall be managed. As a result, not only the coherent legal system was impaired, but the rights of villagers were also endangered. The vote right is a clear example. Although the Legislation Law of the People's Republic of China (hereafter referred as the Legislation Law) indicated this right as an absolute and constitutional political right, many local governments yet imposed their own restrictions ${ }^{\mathrm{b}}$ There are more than nine distinct regulations as to the registration issue of villager voters shall they work outside the village or hold hukou not registered in the village[1]. This obviously defies the coherency of the legal system.

\subsection{The controlled operation encroached the right of autonomy}

According to the Organic Law of Villagers Committees (Articles 2, 5, 11, 12, and 15), the generation of villagers election committees and the nomination, the host and the generation of villagers committees are within the realm of villagers' autonomy. Any individual or organization cannot impose their own willingness upon it.

In the beginning phase of villagers' autonomy when democracy was poorly understood in the vast Chinese rural areas, it was necessary for the local authorities to guide, assist and help village elections. Unfortunately, in many places, the "guidance, assistance and help" became sheer interferences. In the $\mathrm{Wu}$ and Bai villages of Jinhua, Zhejiang, the township CPC committee and the township government violated the legal principle and intervened the villagers' autonomy [2][3]. Some township authorities in Shaanxi directly appointed candidates or even secretly decided committee members, and shattered the rule that all candidates must be "directly nominated by villagers registered for the election". In Yuci, Shanxi, the village election was hosted by town governors, which resulted the villagers election committees in an empty shell [4]. In recent reports on village elections written by the central regulatory departments, administrative interventions are also regarded as one of the most critical issues. The internal functionality of the villagers' autonomy as well as their own rights are encroached by these interventions. In the long run, the improvement of abilities to carry out villagers' autonomy and the institutional development are also endangered.

\subsection{The enforced democracy extinguished real passions}

China's villagers' autonomy arose in a period when the old community economy was replaced by a new private economy, represented by the implementation of the household contract responsibility system. The emerged gap between the central government and the local society called for a fresh social management system, especially an endogenous democracy.

Although the villagers' autonomy has received legal recognition as the fundamental institution in grassroots rural management, it has not been fully accepted by local CPC committees and governments as they worried that it might weaken their control and threaten the rural stability. In the

${ }^{\mathrm{b}}$ For example, the revision in March 2012 of the Election Methods of Villagers Committees of Zhejiang Province removed the article that "all villagers with more than one year's experience of village works, willing to participate in the election and are agreed in the conference of all villagers or village delegates" shall be registered as voters. 
name of "guidance, assistance and help", these authorities recklessly intervened into villagers' autonomy and made the democracy that was endogenously needed as exogenously imposed. As a result, many villagers lost their passions for villagers' autonomy. For example, in some sampled areas of Gansu and Shaanxi, only $30 \%$ of the surveyed villagers agreed that the village election is an event of their own interests and they shall take active roles in it [5]. In some sampled areas of Hainan, $38.7 \%$ of the surveyed villagers indicated no interest in elections [6]. In Yuanyang and Yaozhou villages of Jingmen, Hubei, the villagers' passion for elections kept fading because of the over-control by the township government [7]. A more radical opinion as demonstrated by a survey of 40 villagers in Jiangxi points to the indifferent attitude among villagers as the culprit of the failure of villagers' autonomy [8].

\subsection{Huge costs were incurred by overlapping management}

Organization departments and discipline inspection departments of the CPC, the internal and judicial affairs committee of the National People's Congress, and the departments of civil administration, agriculture, and security at all levels of government are all relevant public authorities of villagers' autonomy and village elections in China. This multilateral, cooperative management seems to be an effective way to strengthen the leadership and control over the villagers' autonomy, but in fact, it only incurred huge administration costs. This is evident in the experience of village elections in Rui' an and Huzhou of Zhejiang [9].

\section{Resources to develop autonomy by law}

\subsection{Experiences}

More than 30 years have been passed since the villagers' autonomy emerged in China, and nine rounds of village elections have been organized up to date. The abundant experiences accumulated through the process will be an invaluable resource for the development of the autonomy by law.

\subsection{The advance in the rule of law}

The current version of China's Constitution has not yet been established when the villagers' autonomy emerged. The following recognition by the 1982 Constitution gave the autonomy a constitutional foundation. The revision of the Constitution in March 1993, which clearly stated to "establish a socialist country ruled by law", further made this autonomy a case or representation of how the central government's intention will be fulfilled. Compared with the 1980s, China's legal environment has been greatly ameliorated. The Organic Law of Villagers Committees issued in November 1998 also provides this autonomy with legal protections. The development of the autonomy by law can now receive more legal resources.

\subsection{Mental thoughts}

The establishment of a democratic institution is in the meantime a process of introducing the idea of democracy among the people. An investigation of 20 villages in the " $T$ " county of Jiangxi found a significant positive role of the villagers' autonomy and village election in activating local farmers' consciousness of civil rights and fostering the growth China's civil society [10]. The experience of Beilaohao Village of Lishu County, Jilin, also known as the "first Chinese village with haixuan (nomination and election by the masses)", also revealed that democracy brought along social and political development [11]. The increased participation into the villagers' autonomy by Chinese farmers cultivated necessary mental thoughts for improving the autonomy. 


\subsection{The economic and social development}

Economic development tends to benefit the grassroots democracy. In China, the villagers' autonomy was more easily advanced in richer provinces [12]. And the village election was positively related with Zhejiang's economic development [13]. Same results are found in Guangdong as well [14]. After the taxation reform in $2006,{ }^{\mathrm{c}}$ villagers committees became less controlled by the governments, while the latter shifted towards providing services instead [15]. Hence, the development of villagers' authority now enjoys a freer space.

\subsection{The political development}

China's administration reforms, which changed the role of governments and encouraged the innovations in social management, provided a political ground for improving the villagers' autonomy.

\section{How to fulfill the villagers' autonomy}

\subsection{Complete the legislation system and foster the rule of law}

First of all, the placement of the villagers' autonomy in the Constitution shall be corrected. The autonomy is now specified in Section 5 ("Local People's Congresses and Local People's Governments") of Chapter 3 ("National Institutions"). Therefore, villagers committees can easily be mistaken as subordinate institutions of the government, which is conceptually incorrect. And this will encourage an illusion that that their autonomy rights are subject to the authority. As suggested by the practice over the past 30 years, the villagers' autonomy is an important political right of villagers. It shall be acknowledged, together with the autonomy of urban residents, as a constitutional and basic political right of all the Chinese people, and be specified in the Chapter of "The Fundamental Rights and Duties of Citizens".

Secondly, the Organic Law of Villagers Committees shall be completed. Although this law received a revision in October 2010, several issues still need to be amended. For example, the law specified that "standing committees of province-level people's congresses can formulate implementation measures according to this law and local actual situations." However, according to the legislation law, "the system of grassroots level self-governance" and "the deprivation of a citizen's political rights" are both absolutely reserved legal items that are only subject to laws legislated by the National People's Congress and its standing committee. Thus, the implementation measures of villagers' autonomy can only specified by the Organic Law of Villagers Committees itself, and local authorities cannot be authorized. Aside from this issue, additional improvements are also needed with respect to the village relationships, the composition, duties and the election of villagers committees, the villagers' conference and the conference of delegates, and the democratic management and inspections.

Thirdly, the legal system of the villagers' autonomy shall be fulfilled. In addition to the current Organic Law of Villagers Committees, the Villagers' Autonomy Law and the Election Law of Villager Committees both need to be legislated.

\subsection{Reform methods and replace interventions by macro directions}

The Organic Law of Villagers Committees indicated that "town-level people's governments can guide, assist, and help villagers committees, but must not intervene their autonomy". The traditional government intrusions, hence, must be eliminated and replaced by macro directions. This will facilitate the shift from the autonomy by power to the autonomy by law, foster innovative management of the villagers' autonomy by township governments, and promote a healthy interaction between the development of the villagers' autonomy and the shift of government roles.

\footnotetext{
' Taxation used to account for $70 \%$ of village committees' total administrative works.
} 


\subsection{Abandon redundant regulations and make the village CPC bodies the political center}

As indicated in the fourth article of the Organic Law of Villagers Committees amended in October 2010, "village CPC bodies shall serve as the political center and exhibit its leadership in accordance with the Party Constitution, lead the villagers committees exercise their powers, assist and guarantee villagers in launching autonomy activities and exerting their democratic rights in accordance with the Constitution and laws". Compared with the version before the amendment, the sentence of "lead the villagers committees exercise their powers" is added. This clarifies the leadership of the village CPC bodies over villagers committees.

The emphasis of vertical leaderships within the CPC system, rather than administrative inspections and even intrusions, the central government found a new yet much softer way to regulate the villagers' autonomy. Historical lessons suggested that as long as the leadership of the village CPC bodies is respected, adjust their roles in line with the trend of the villagers' autonomy, and promote their leading abilities and popular trust, the villagers' autonomy can be led by them successively.

It has to be noted that the leadership by the village CPC bodies does not imply a replacement of villagers committees or intrusions into their autonomous business. CPC bodies must carry out their works within the realm specified by law and avoid direct interferences of specific affairs of the villagers' autonomy. They shall assist and help independent works by villagers committees as well as protect the villagers' autonomy by exerting political leaderships, coordinating conflicts and problems in executing the villagers' autonomy, recommending proper candidates to villagers committees, exercising pioneering and exemplary roles, and carrying out public education and promotions.

\subsection{Construct institutions and enhance legal protections of the villagers' autonomy}

In the Organic Law of Villagers Committees, resolutions to disputes related to the villagers' autonomy and legal remedies are mainly specified in Articles 17 and 36. It is evident that the infringement in implementing villagers' autonomy includes the civil tort and the administrative tort in general. And the infringement frequently occurred as villagers committees impaired villagers' rights to vote or be voted (where the only legal remedy is administrative, i.e. through government inspections and decisions), and encroaches villagers' lawful rights and interests (where both civil and administrative via corrections ordered by governments - remedies can be adopted).

However, analyses of the above two articles showed the following problems regarding to the design of legal remedies. First of all, there are not sufficient regulations about the infringement of the villagers' autonomy by the national public power. The legislation gap must be filled such that township governments can be pushed to change their roles and protect the villagers' autonomy. Secondly, legal remedies are still in lack. As a result, the villagers' autonomy heavily relies on the administrative power and the autonomy by law is challenged. The prosecutability of administrative tort in the villagers' autonomy must be clearly specified. Thirdly, the criminal infringement shall receive more attention to protect the villagers' autonomy fully. Article 256 of the Criminal Law of the People's Republic of China indicated "in election of the deputies to the people's congresses and the leading members of State organs at various levels, disrupts election or obstructs the electorate and deputies from freely exercising their right to vote and to stand for election by such means as violence, threat, deception, bribery, falsification of electoral documents or false report of ballots" as criminal actions. Similar means during village elections shall also be subject to the regulation of this article through proper amendments.

\section{Conclusion}

The villagers' autonomy has been substantially impaired by the rule by power in China. The only resolution to this conundrum is the autonomy by law. Thanks to practices of the villagers' autonomy during the past 30 years and the social economic development in the rural sector, the advancement of 
the rule by law, and the promotion of the idea and abilities of democracy among villagers, to fulfill the autonomy by law becomes possible. This is also the future of China's institutional development with respect to the villagers' autonomy.

\section{References}

1. M. Tang, Several legal issues of voters' registration in the election of villagers committees, Journal of Huazhong Normal University (Humanities and Social Sciences), 2004(1).

2. $\mathrm{X}$. Li and F. Lu, Analyses on disordered villagers committee elections, Journal of Jingmen Vocational Technical College, 2000(3).

3. F. Lu, Difficult but beneficial attempts of democracy, China Rural Survey, 2000(2).

4. Y. Shi, F. Gao, and B. Ren, Methods and effectiveness of democratic elections in rural China, Management World, 2004(1).

5. Z. Chang, The legal practice in rural China, Gansu Agriculture, 2011(4).

6. D. Li, Villagers' autonomy in the eyes of villagers, in the International Symposium on the Twentieth Anniversary for Implementing the Organic Law of Villagers Committees, June, 2007.

7. X. He, Why the village election receded, China Rural Survey, 1998(4).

8. T. Xiao and X. Qiu, The attitude and actions of voters in village elections, China Rural Survey, 2001(5).

9. M. Mao, J. Fang, and G. Fang, Analyses and reckonings on several issues in the election methods of the villagers committee, in the Conference Proceedings of Rural Grassroots Democracy and Local Legislation of Zhejiang Province, November, 2011.

10. L. Li, The politics of introducing township elections in rural China, The China Quarterly, 2002(171).

11. T. Xia and M. Tang, The absent democratic cooperation in the villagers' autonomy and its solutions, Jiangxi Social Sciences, 2010(11).

12. K. O'Brien, Implementing political reform in China's villages, Australian Journal of Chinese Affairs, 1994(7).

13. B. He and Y. Lang, Searching for the Balance between Democracy and Authority, Huazhong Normal University Press, 2002, pp. 162-179.

14. Z. Guo, Village elections and the development of democracy in China observed foreign scholars, China Rural Survey, 2003(5).

15. Z. Hu and M. Tang, The villagers' autonomy in developing a new socialist countryside, CASS Journal of Political Science, 2009(1). 